\title{
RELATION OF THE FARMERS INOVATIVENESS LEVEL TO THE LEVEL OF ORGANIC PRACTICE SUSTAINABILITY IN SUNGAI RENGAS VILLAGE, SUNGAI KAKAP, KUBU RAYA, WEST KALIMANTAN
}

\author{
WIJANARKO ${ }^{1)}$, EDWARD ZUBIR ${ }^{2)}$ \\ UPBJJ-UT Pontianak ${ }^{1}$, UPBJJ-UT Banjarmasin ${ }^{2)}$ \\ E-mail : wijanarko@ut.ac.id ${ }^{1}, \underline{\text { edoz@ut.ac.id }}{ }^{2}$
}

\begin{abstract}
The success of agricultural development is strongly related to how far information of innovation reached the farmers. Here lies the importance of agricultural outreach communication by observing the level of farmers innovativeness in practicing organic cropping pattern. This research observes the relation between farmers innovativeness with the organic farming practice level of sustainability. The innovativeness variables being observed are the socialeconomy, individual and communication activities. Variables being observed in the organic farming practice is the implementation of organic farming principles such as over three years land conversion, usage of local seeds, the use of organic fertilizer, the use of non chemical pesticides and division of land and irrigation from the non-organic farming. This research was carried in the Sungai Rengas Village, Sungai Kakap Sub-district, Kubu Raya District, West Kalimantan. The research employs explanatory research method, with data collection by survey. This research took samples of 36 respondents. Primary data in the research was collected through questionnaires accompanied by interviews to a number of organic farmer in Sungai Rengas Village, Sungai Kakap Sub-district, Kubu Raya District. Secondary data was taken from the local government institution (village/sub-district), Department of Lands, Agricultural and Plantation Office, or related statistical data accessible in the internet. After the data was collected, it was coded and input into SPSS.

The research result pointed out that the level of farmers innovativeness to organic farming is related to the variables of cosmopolitanism, capital ownership, courage to take risks, involvement in group activities and intensity in relation with external parties. The choice on communication channel using interpersonal communication channel relying on face-to-face communication with fellow farmers and outreach officers. There are no significant relation between the choice of communication channel with the organic farming practice sustainability. This means farmers only rely on interpersonal medium. Therefore, organic farming outreach in farmer groups level needs strengthening. Another recommendation is strengthening the interpersonal communication network through public figures and fellow farmers as the key to success in organic farming practice.
\end{abstract}

Keyword: Farmers innovativeness, organic farming, interpersonal communication. 


\section{FOREWORD}

Background

As an autonomy area formed in 2007, Kubu Raya District made agricultural sector as its main sector of economy development. The sector has proven to be a significant contributor to Kubu Raya District PDRB by as much as $18.88 \%$ from the total Gross Regional Domestic Production (Produk Domestik Regional Bruto/PDRB). In 2010 the production of rice in Kubu Raya District was 183,851 tonnes and 4,318 tonnes of dry field rice. Compared to the previous year it slightly decrease by $5,61 \%$. The decrease in rice production was caused by the decrease of harvest area from 59,603 Ha to 55,796 Ha or it decreased by $6.39 \%$ (Kubu Raya District Office of Statistics, 2011).

Related to the development program, in 2010 the government of Kubu Raya District built activity centers by dividing the development region into three areas that are PKN (Pusat Kegiatan Nasional, National Activities Centers) comprises Sungai Raya Sub-District; PKL (Pusat Kegiatan Lokal, Local Activities Centers) comprises Sub-districts Sungai Kakap, Rasau Jaya, Kubu, Batu Ampar and Sungai Ambawang; and PPK (Pusat Pelayanan Kawasan, Area Service Center) comprises Sub-districts Terentang, Teluk Pakedai and Kuala Mandor B. Apart of this, the government have also planned the development of city system by forming three units of development areas (Kubu Raya District Office of Statistics, 2011).

Area development in support to the agricultural sector appointed Sungai Kakap Sub-district as the Integrated Agribusiness Area (Kawasan Usaha Agribisnis Terpadu/KUAT) in 2005 by the West Kalimantan Provincial Government. This area was later names KUAT Kakap Bangkit and is located $20 \mathrm{~km}$ from Pontianak City and was later appointed as the center of rice production to buffer the stocks of Pontianak City (Burhansyah and P Melia, 2010).

Based on the data of Kubu Raya Office of Statistics in 2013 the usage of rice field area in Sungai Kakap sub-district was $34,767 \mathrm{Ha}$ or $40 \%$ of the total land usage, while the average rice production was $35.90 \mathrm{Kw} / \mathrm{Ha}$ with the total of rice production 63,715 tonnes (Kubu Raya District Office of Statistics, 2013).

Sungai Kakap is currently the location of organic rice farming development, specifically in Sungai Rengas Village. The organic rice farming development was initiated by PTPMN XIII, Aliksa Organik Foundation and Tanjungpura University. The average production of organic rice after the organic cropping pattern was implemented was 7.4 tonnes/Ha when previous yield was 23 tonnes/Ha before it was organic (Source: http://kuburayamandiri.blogspot.com, accessed in 15/02/2013).

The success of agricultural development is strongly related to the extent of innovation information received by farmers through interpersonal channels and the mass media (Rogers and Shoemaker, 1971). This innovation information aims for information literacy among farmers so they are able to decide, access and evaluate information (Rockman in Dinpanah and Lashgarara, 2011). Finally the use of information source will lead to social changes within the society (Abbott and Yarbrough in Dinpanah and Lashgarara, 2011).

According to the research result of Subagiyo (2005) in Pertiwi (2009), characteristics related to farmers innovativeness in receiving information and 
external innovation are among others; age, level of education and work experience, motivation, exposure to information from the media, cosmopolitanism, also involvement in organizations. Another case with the research result of Syafruddin (2003) in Pertiwi (2009), decisive factors of innovation adoption are found to be: knowledge, work motivation, attitude, level of education, experience, workforce, capital, production means and market availability. From the results of these researches it could be observed that there are a lot of factors influencing one's innovativeness in accepting an introduction, which began with information reception.

One of the agricultural innovation is organic farming. According to Suhardjono (2006), the issue of organic farming movement is a response to the green revolution cropping pattern emphasizing the intakes of manufactured chemicals. Organic farming movement does not stop at social economy movement, it is also a moral movement in preserving the environment. The principle of organic farming sustainability is based on the principles of health, ecology, justice and preservation (IFOAM, 2013).

On this basis, observation could be made on the extent of organic farmers in Sungai Rengas, Sungai Kakap Sub-district, Kubu Raya District in having an innovativeness level in implementing organic farming practices. Also to see the relation of level of innovativeness to the practice of sustainable organic farming.

\section{Problem Formulation}

Problem formulation can be described as the followings:

1. What is the description on farmers innovativeness in Sungai Rengas Village, Sungai Kakap Sub-district?

2. How is the sustainability of the organic farming practice?

3. What is the close relation between the characteristics of farmers innovativeness to the level of organic farming practice sustainability?

\section{Research Purposes}

In general the research aims to discover the level of farmers innovativeness level and the sustainability of organic farming practice. In specific, the purposes of this research are:

1. Describing the farmers innovativeness characteristics in Sungai Rengas Village, Sungai Kakap Sub-district.

2. Describing the level of organic farming sustainability in Sungai Rengas Village, Sungai Kakap Sub-district.

3. Describing the relation between farmers innovativeness sustainability level the of organic farming practice .

\section{Research Usability}

This research is hoped to be able to provide some usability, among others:

1. Providing stakeholders with information on the characteristics of farmers innovativeness in relation to the choice of communication channels in the sustainability practice of organic rice farming business management in the KUAT area of Sungai Rengas Village, Sungai Kakap Sub-district, Kubu Raya District.

2. Agent of changes can find appropriate techniques in delivering beneficial innovation information to participants in their target area.

3. This research is hoped to be able to contribute ideas to parties assessing the farmers communication channels. 


\section{METHODOLOGY}

The research is designed to be an explanatory research, explaining the corelation between variables by testing the hypothesis. The research aims to describe the characteristics of organic farm of Sungai Rengas Village farmers, Sungai Kakap Sub-district, Kubu Raya District and its relation the organic farming practice sustainability.

This research was carried out at the area of Sungai Rengas Village, Sungai Kakap Sub-district, Kubu Raya District. Sungai Kakap Sub-District is an Integrated Agribusiness Area (Kawasan Usaha Agribisnis Terpadu/KUAT) appointed in 2005 ans as the rice producing are for West Kalimantan in general and Kubu Raya District in specific. In 2010 it was appointed as the Local Activities Center (Pusat Kegiatan Lokal/PKL) development area by the Kubu Raya District Administration with agricultural as the main sector. Sungai Rengas Village, Sungai Kakap Sub-district is a pilot village for organic farming development in West Kalimantan. The number of selected samples are 36 farmers as respondents for this research.

Type of data collected is primary and secondary data. Primary data was collected directly from population members who are the research samples (respondents). Primary data was collected through research questionnaires by interviewing the respondents. Secondary data was gained from local government, related institutions and rice farmer groups in the research area, functioning as complimenter and supplement to the primary data.

In this research, the instruments needed testing so it could be utilized as a valid and main instrument. Kerlinger (2006) stated that an instrument is considered valid when the measurement can be used to appropriately measure the concept that needs to be measures. The mainstay of an instrument is related to the consistency achieved by a measuring tool, although it is used repeatedly on a same or different subjects (Kerlinger, 2006)

Primary data in this research is collected through questionnaires accompanied by interviews to a number of organic farmers in Sungai Rengas Village, Sungai Kakap Sub-district, Kubu Raya District. Direct complementary data were also gathered through interviews with PPL dan the Kubu Raya District agriculture office that assists farmer and public figures who understand the groups issues. The secondary data collected from the local governmental institution (village/sub-district), Department of Lands, Agricultural and Plantation Office, or related statistical data accessible in the internet.

After data is collected, it was coded and input on SPSS. The data is analyzed using descriptive statistic analysis by presenting the distribution of frequency, percentage, average, median and deviation standard, also inferential statistic analysis using non-parametric statistic with Spearman Rank Correlation test $\left(\mathrm{r}_{\mathrm{s}}\right)$, with formulation as follows (Siegel, 1994):

$$
\mathrm{r}_{\mathrm{s}}=1-\frac{6 \sum \mathrm{d}_{\mathrm{i}}^{2}}{\mathrm{~N}^{3}-\mathrm{N}}
$$

Notes: $\quad r_{\mathrm{s}}=$ Spearman rank correlation coefficient

$\mathrm{N}=$ number of Respondents

$\mathrm{d}_{\mathrm{i}}=$ ranking difference between two variables. 
With hypothesis testing:

$$
\begin{array}{ll}
\mathrm{H}_{0} & : r_{\mathrm{s}}=0 \\
\mathrm{H}_{1} & : \mathrm{r}_{\mathrm{s}}>0 \text { or } \mathrm{r}_{\mathrm{s}}<0 .
\end{array}
$$

The calculation principle is :

$$
\begin{aligned}
& \mathrm{r}_{\mathrm{s}} \text { hit }<\mathrm{r}_{\mathrm{s}} \text { table } \longrightarrow \text { Receives } \mathrm{H}_{0} \\
& \mathrm{r}_{\mathrm{s}} \text { hit } \geq \mathrm{r}_{\mathrm{s}} \text { tabel } \longrightarrow \text { Resists } \mathrm{H}_{0}\left(\text { Receives } \mathrm{H}_{1}\right) .
\end{aligned}
$$

Significance level in level $\alpha=0,05$ is 0,305 and $\alpha=0,01$ is 0,432 by using Table A.4 (Walpole, 1995).

\section{RESULTS AND ANALYSIS \\ General Description of Research Location}

Based on the Main Demography Record of Sungai Rengas Village in year 2013, Sungai Rengas Village is under the Sungai Kakap Sub-district, Kubu Raya District with 4,200 Ha area. Sungai Rengas Village is bordering with Kapuas river at the north, Pal V and Pal IX at the South, Pontianak Municipal at the east and the west border is with villages Sungai Kipah, Jeruju Besar and Sui Itik. Population of Sungai Rengas Village is 19,928 with 4,560 households, comprises 9,201 men and 10,727 women. The majority of Sungai Rengas populations is Moslem. Ethnic groups in Sungai Rengas Village are Bugis, Malays, Javanese, Madurese, Chinese, Dayak and Batak.

Total ricefield harvest area in Sungai Rengas Village is 1,850 Ha with total production of 4,995 tonnes, yield per $\mathrm{Ha}$ is 2.7 ton/ha. Number of farmer households working in agricultural field is 1,911 households. Pest for rice plants in Sungai Rengas village are rats, leafhoppers, sundep (rice white stemborer/australian caterpillar), sangit (Leptocorisa acuta). Less than $50 \mathrm{~cm}$ deep Solum layer is as wide as 1,850 Ha. There are 14 rice millers in Sungai Rengas Village with 30 workers, producing as much as 270 tonnes/Ha. Rice market in Sungai Rengas Village is the village and its surrounding.

Based on the research of Burhansyah and P Melia (2010), rice farming in West Kalimantan is planting twice a year, during the rainy season and dry season. The rainy season variety is the local variety that yields within 4-5 months. Planting season is usually on September to October and harvest began on February to March. During the dry season, rice is planted in April to May and harvested in July to August.

\section{Level of Innovativeness}

Farmer innovativeness level is measured based on social economy characteristics variable, individual characteristic and communication characteristic. Social and economy characteristic of the respondent can be observed from the age, number of dependents, level of education, leadership, living standards, land ownership, capital ownership and cosmopolitanism. Individual characteristic includes the variables of level of empathy, abstraction ability, social participation, communication activities, courage to take risks, and futurism level. Respondent's communication characteristics comprises variables of social participation level, communication activities. 
Rogers and Shoemaker (1986) stated that farmers innovativenes can be observed from their innovativeness characteristics. According to Rogers and Shoemaker, a more innovative person is a person who has the following characteristics:

(1) Social-economy characteristic, includes: better level of education, higher social status, bigger level of mobility/cosmopolitanism, larger land area, more capital, having specific job and more oriented to product commercialization.

(2) Personality characteristic that is demonstrated by: big empathy, not/less dogmatic, better abstraction ability, rationalist, high intelligence, nodding toward change, willing to take risk and not believing in fate (futurism).

(3) Communication characteristic that consists of: high level of social participation, often engaging in interpersonal communication, often engaging social relation with strangers and with agents of change, often utilising the mass media to gain information, high level of leadership and delighting to be within a system with modern norm.

The research result on organic farmers innovativeness level refers to characteristic stated by Rogers and Shoemaker, limited within the following aspects/characteristics: (1) social economi characteristic, comproses: level of education, level of leadership, level of mobility/cosmopolitanism and capital ownership; (2) characteristic level displayed through: level of empathy, ability of abstraction (level of abstraction), courage in taking risks and level of futurism; also (3) communication characteristic, comprises: level of social participation, interpersonal communication activities, level of exposure to media, also level of participation in outreach activities.

Based on the questions and statements proposed to the respondents, a scoring system is made to the scale of provided answers. Scores generated from the respondents' answers are calculated according to the observed group of variables, and then averaged. The average of answer scores is compared to the median score of each answers, to determine the level of the farmer's innovativeness. In this research, innovativeness level is regarded as trending in high when the average score is bigger than the median score of the answers scale. Innovativeness level can be seen in Table 1. 
Table 1. Statisticial Description of Respondent's Innovativeness Level based on the Average Score of Respondents' answers

\begin{tabular}{|c|c|c|c|c|c|}
\hline No & Variables & $\begin{array}{l}\text { Low } \\
\text { Score }\end{array}$ & $\begin{array}{l}\text { High } \\
\text { Score }\end{array}$ & $\begin{array}{l}\text { Median } \\
\text { Score }\end{array}$ & $\begin{array}{c}\text { Average } \\
\text { Answer } \\
\text { Score } \\
\end{array}$ \\
\hline $\mathbf{A}$ & $\begin{array}{l}\text { Social Economy } \\
\text { Characteristics }\end{array}$ & & & & \\
\hline 1 & Educational Level & 1 & 4 & 2.5 & 1.97 \\
\hline 2 & Cosmopolitanism Level & 1 & 3 & 2 & 1.42 \\
\hline 3 & Capital Ownership & 1 & 3 & 2 & 2.02 \\
\hline 4 & Land Ownership & 1 & 3 & 2 & 2.30 \\
\hline 5 & Social Status & 1 & 3 & 2 & 1.93 \\
\hline B & Individual Characteristic & & & & \\
\hline 1 & Level of Empathy & 1 & 3 & 2 & 1.75 \\
\hline 2 & Level of Abstraction & 1 & 3 & 2 & 1.76 \\
\hline 3 & Level of Courage Taking Risks & 1 & 3 & 2 & 2.22 \\
\hline 4 & Level of futurism & 1 & 3 & 2 & 1.77 \\
\hline $\mathbf{C}$ & $\begin{array}{l}\text { Communication } \\
\text { Characteristic }\end{array}$ & & & & \\
\hline 1 & Level of Social Participation & 1 & 3 & 2 & 2.47 \\
\hline 2 & $\begin{array}{l}\text { Communication activities } \\
\text { Intensity of Relations with }\end{array}$ & 1 & 3 & 2 & 2.23 \\
\hline 3 & $\begin{array}{l}\text { External Party } \\
\text { Participation in Group }\end{array}$ & 1 & 3 & 2 & 1.47 \\
\hline 4 & Activities & 1 & 3 & 2 & 1.99 \\
\hline
\end{tabular}

Table 1 shows that the social economy characteristic variables with average answer score higher than the median score is on land ownership (2.30) and capital ownership (2.02). According to Rogers and Shoemaker (1986) that a more innovative person generally have better land and capital in their farm. On the contrary the scores of variables education (1.97), level of cosmpolitanism (1.42), social status (1.93) have very low scores, under the median scores for answers. This can prove that the respondents lack of innovation when it's related the low education, lack of cosmopolitanism and not having good social status within the society.

The average scores in individual characteristics have a low average answer scores, which are level of empathy, level of abstraction, and level of futurism. It means the level of innovativeness based on respondents' individual characteristics tends to be low. Only the scores of courage in taking risks in organic farming is beyond the score average (2.22). It mean the respondents have innovativeness level for organic farming.

The average scores in communication characteristics variables, only the social participation level (2.47) and communication activities (2.23) have higher answer score average compared to the median scale of answer scales. According to Rogers and Shoemaker, one characteristic of one's innovativeness based on communication characteristic is having high participation in their environment and having good interpersonal communication activities. There were two low scoring variables which are the component of intensity relation to parties outside of the village (1.47) and participation in group activities (1.99). Intensity in 
relation to parties outside of the village proves that respondents rarely seek and exchange information in organic farming with other parties who understand about organic farming, such as an outreach officer. A low participation in the outreach activity proves that the respondents aren't active in attending outreach and training activities carried out by related institution. Most are just being passive group members.

\section{Organic Farming Practice Sustainability}

The level of sustainability of organic farming practice is related to the sustainability of the organic farm itself economically. The level of organic practice sustainability can be observed through the practice of organic land conversion, the use of organic fertilizer, organic pesticide, local seeds and separating between the organic and non-organic land and irrigation system (Widiarta, et al., 2011). The economic sustainability can be observed through the productivity level yields in organic farming.

Organic farming practice is inseparable from the process of organic farming management starting from land preparation, propagation, fertilization and pest control, the use of local seeds and irrigation utilization. Land conversion process to become organic requiring more than a short period. Conventional land contains a lot of chemical intakes from chemical fertilizer and the use of pesticide. Usually the land conversion to organic takes 3 years, but in practice some are done less than 3 years. Like what the Sungai Rengas farmers were doing, gradual organic land conversion. While shifting into an organic land, they still use conventional farming system. This is what makes farmers assume that it is difficult to make an land purely organic, because it takes a long time. This proves that organic farming concept is yet to be applied by the respondents in this land conversion. Thus, respondents maintain conventional farming system or not yet implementing organic farming.

The use of organic fertilizer in organic farming system organization is compulsory because fertilizer is important nutrition for the rice plant development. To observe the implementation of organic fertilizing by respondents, measurement can be based on: entirely using organic fertilizer, a mix between organic and chemical fertilizer, and entirely chemical fertilizer. Based on the research result the use of chemical fertilizer by respondents is quite hight. This proves that respondents return to conventional farming emphasizing on the usage of chemical fertilizer. The type of chemical fertilizer being used are urea and TSP. On the contrary there are 2 respindents who use organic fertilizer in their farming management. The organic fertilizer they use is compost. The high usage of chemical fertilizer in the organic group proves that respondents aren't applying organic farming. Organic farming sustainability is not visible in Sungai Rengas Village.

Local seeds used by the organic farmers in Sungai Rengas are generally the Sri Ayu rice seedlings. Sri Ayu is the local seeds for organic farming. The use of local seeds alone does not guarantee the implementation of organic farming, other phases have to be regarded in organic farming. This often create an incorrect perception, that organic farming is observed only by the usage of local seeds.

Organic farming implementation in pest control and disease control on rice plants using natural elements from the natural enemies of the pests and the usage of natural ingredient to eliminate disease. Sungai Rengas itself has one insect 
trapper used for organic farming. But due to the wide area that are not covered, the use of this tool is not prevalent to all farmlands. Research result proves that the majority of respondents using chemical pesticide. This can be dangerous for the environment.

One of organic farming implementation is separating the organic to the nonorganic land. This situation is difficult to since the condition of irrigation is integrated in one spread of ricefield in Sungai Rengas Village. Generally all respondents stated there are no separation betwen organic and non-organic land. Based on this, organic farming is yet being implemented because organic land must be separated from the irrigation of the non-organic land.

Based on the previous description, it could be concluded that organic farming practice in Sungai Rengas Village is not sustainable. This condition can be observed from the 5 aspects of organic farming, which are: land conversion, the use of local seeds, the use of organic fertilizer, the use of natural pesticides and organic farming land division. Only one aspect is visible that is the use of local seeds Sri Ayu, yet this cannot be categorized into organic farming. Nevertheless there are 2 respondents who still apply organic farming in the aspect of; land conversion, the use of organic farming, the use of natural pesticide and the use of local seeds. Both respondents are the head and the treasurer of the organic farming group.

Organic farming sustainability can also be observed from the respondent economy sustainability. Average rice production in Rengas Village yields 1500$2500 \mathrm{~kg} / \mathrm{Ha}$. With wet grain priced $\mathrm{Rp} 4,300 / \mathrm{kg}$, the average income of farmers

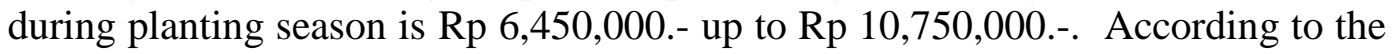
respondents, the middlemen equalize the price of organic and non-organic farming. Thus respondents shift their organic farming back into conventional farming they had practiced previously. Based on the research result of Widiarta Et al. (2011) that organic farming practice is proven to have positive impacts toward farmers' economy sustainability. But in this case the farmers discontinue their organic practice because the price is the same with non-organic. Thus, the organic farming practice is not sustainable economically.

\section{The Relation of Farmers Innovativeness to the Organic Farming Practice Sustainability}

Based on the rank spearman correlation test it is discovered that only education variables that correlates with productivity, income and organic practice (see table 2). Level of education has significant relation to the farming productivity level $(r=0.449)$. Which means the higher level of education means higher level of farming productivity. Education is also related to the level of income in farming $(r=0.373)$. Which means the higher the education means higher level of income. Level of education also correlates with organic farming practice $(r=0.551)$. The higher the education level, then the respondents will be more likely to implement organic farming. 
Table 2. Results of Rho-Spearman Correlation Test between Social Economy Characteristics with the Organic Farming Practice Sustainabilty

\begin{tabular}{llccc}
\hline No. & \multicolumn{1}{c}{ Indicators } & Productivity & Income & Organic Practice \\
\hline 1. & Education & $0.449 * *$ & $0.373^{*}$ & $0.551^{* *}$ \\
2. & Social Status & 0.205 & 0.217 & 0.319 \\
3. & Cosmopolitanism & 0.016 & 0.017 & 0.181 \\
4. & Land Ownership & 0.029 & -0.048 & -0.218 \\
5. $\quad$ Capital Ownership & 0.180 & 0.186 & 0.302 \\
\hline$*$ = significant on $\alpha$ 5\% & & & \\
$* * \quad=$ significant on $\alpha 1 \%$ & & &
\end{tabular}

Individual characteristic is also related to the practice of organic farming sustainability especially in the variables of abstraction level, courage in taking risks and level of futurism. All three have significant relation to the practice of organic farming (see table 3). Abstraction level is significantly related to organic practice $(r=0.561)$. Which means the easier the respondent comprehending and understanding a message from the material being conveyed it would be easier to implement it into organic practice.

The courage in taking risks also significantly related to organic practice $(\mathrm{r}$ $=0.744$ ). Which means better understanding on the risks being taken i deciding to go organic, the respondent is prepared to face failure. With this attitude the respondent dares to apply organic farming and practice it into their agribusiness. This is in accordance to the research of Rahayu (2011) that most organic farmers are risk averse.

Futurism is also significantly related to the practice of organic farming $(\mathrm{r}=$ 705). A vision of the future and not believing in fate will influence the practice of organic farming. Respondents who believe in fate will not practice organic farming. Because for them organic farming is filled with failure risks and thus have no bright future of agribusiness.

Table 3. Results of Rho-Spearman Correlation Test between Individual Characteristics and Organic Farming Practice Sustainability

\begin{tabular}{clccc} 
No. & \multicolumn{1}{c}{ Indicator } & Productivity & Income & Organic Practice \\
\hline 1. & Level of Empathy & 0.227 & 0.194 & 0.139 \\
2. & Level of Abstraction & 0.213 & 0.266 & $0.561^{* *}$ \\
3. & Level of Risk & 0.158 & 0.227 & $0.744^{* *}$ \\
4. & Level of Futurism & 0.140 & 0.207 & $0.705^{* *}$ \\
\hline * significant on $\alpha$ 5\% & & &
\end{tabular}

$* *$ = significant on $\alpha 1 \%$

Communication characteristics that are communication activities, involvement in group activities and frequency of relation with external parties turn out to have significant relation with organic practice sustainability. As with the research results from Okwu and Daudu (2011), that communication activities will impact the behavior change in this case in organic practice. Communication activities is significantly related with income and organic practice. The higher communication activities in discussion, answering, querying leads to respondent applying organic farming practice and finally can increase the income of their agribusiness. 
Involvement in group activities is also significantly related with productivity, income and organic practice. The higher the respondent's involvement in the group such as being an active group member, attending outreach and training activities leads the respondent to applying organic farming practice. Also it increase their agribusiness productivity and income.

While the frequency of relation with external parties is significantly related to income. The more intense a respondent's relation to external parties such as outreach officers will lead to higher income for their agribusiness because they gain input and information on cultivation. Details can be observed in Table 4 . Table 4. Results of Rho-Spearman Correlation Test between Communication Characteristic to Organic Farming Practice Sustainability

\begin{tabular}{|c|c|c|c|c|}
\hline No. & Indicator & Productivity & Income & $\begin{array}{l}\text { Organic } \\
\text { Practice }\end{array}$ \\
\hline 1. & Social Participation & 0.207 & 0.070 & 0.090 \\
\hline 2. & Communication Activities & 0.256 & $0.341 *$ & $0.578 * *$ \\
\hline 3. & $\begin{array}{l}\text { Involvement in Group } \\
\text { Activities }\end{array}$ & $0.383^{*}$ & $0.423^{*}$ & $0.675^{* *}$ \\
\hline 4. & $\begin{array}{l}\text { Intense Relation with } \\
\text { external parties }\end{array}$ & 0.261 & $0.362^{*}$ & 0.250 \\
\hline
\end{tabular}

\section{Conclusion and Recommendation}

The description of Sungai Rengas farmers innovativeness toward organic farming is generally not good based on the characteristics of social-economy, individual, and communication. Of the 5 social economy characteristic variables only the capital and land ownership are above score average. This proves that the bigger capital and land owned, the more innovative the respondent will be toward organic farming. Individual characteristic only show the variable of courage to take risks above the score average. That means the more a respondent dare to take a decision toward being organic the more they are ready to face the risks of their decision. Communication characteristic has the variables of social participation and communication activities shown to be above score average. That means that the more respondents being involved in social activities in their surrounding society, the more open they are toward new innovation/ideas including about organic farming. In addition to this, the more intense the communication with other parties through discussions, querying and responding, the more open the respondent will be toward ideas from external parties.

Organic farming practice in Sungai Rengas Village is not sustainable. From the 5 aspects of organic farming management, only one management aspect is still being applied, which is the use of local seeds, while the other 4 aspects that are land conversion, organic fertilizers, natural pesticide and irrigation division is not yet applied. In addition, the aspect of organic rice price being equalized with non-organic rice makes farmers returning to the non-organic rice cultivation.

There are no significant corelation between choice of communication channels to the organic farming practice sustainability. This is because in general the respondents use interpersonal communication channels and rarely use electronic and printed medium. Meanwhile the respondents' innovativeness characteristic is related to the organic farming practice sustainability in the 
variables of education, level of abstraction, level of risks, level of futurism, communication activities, involvement in group activities and intensity of relation with external parties.

Furthermore the research recommends that the Department of Agriculture needs to increase the outreach and training activities to farmers in Sungai Rengas Village. Outreach and training materials should use examples that are easy for the farmer to understand so the message conveyed can be easily processed and comprehend that finally the organic farming concepts they adopt from the outreach can be applied in their daily activities. It is necessary to approach public figures and farmer groups. The approach is based on the indicators of the high usage of interpesonal communication channel in Sungai Rengas Village. In addition, strengthening of the existing farmer groups is necessary because the indicator of member involvements in group activities is very low. On matters related to the equal price between organic and non-organic rice, Department of Agriculture needs to provide information on organic produce marketing that is detached from the middlemen networks.

\section{BIBLIOGRAPHY}

Anonim. 2013. Buku Data Induk Penduduk Desa Sungai Rengas (Sungai Rengas Village Main Demography Record), Sungai Rengas Village

Anomin. 2014. Dorong Pertanian Organik, http://kuburayamandiri.blogspot.com. Accessed on 15 January 2014, 14.00 wib

Central Bureau of Statistics West Kalimantan. 2011. Berita Resmi Statistik BPS Provinsi Kalimantan Barat. No. 57/11/61/Th. XIV, 1 November 2011.

Kubu Raya Office of Statistics. 2011. Kabupaten Kubu Raya Dalam Angka 2011 2013. Kabupaten Kubu Raya Dalam Angka 2013

Burhansyah and P Melia. 2010. Kinerja Usahatani Padi Dan Indikator Kesejahteraan Petani Di Sentra Produksi Padi Kabupaten Kubu Raya (Rice Agribusiness Performance and Farmers Welfare in Kubu Raya District Rice Production Center). http://pse.litbang.deptan.go.id/pdffiles. Accessed on 10 February 2012, 14.00 wib

Dinpanah and Lashgarara. 2011. Factors Influencing the Information Seeking Knowledgeof wheat farmers in Iran. African Journal of Agricultural Research Vol. 6(14), pp. 3419-3427, 18 July, 2011. Available online at http://www.academicjournals.org/AJAR

IFOAM. 2012. Prinsip-Prinsip Pertanian Organik [online].[Downloaded on 2013 Apr 3]. Available online at http://ifoam.org.

Kerlinger, F. N. 2006. Asas-asas Penelitian Behavioral. $11^{\text {th }}$ Edition. Simatupang, L. R. And H. J. Koes Soemanto (translators). Yogyakarta: Gajah Mada University Press.

Okwu and Daudu. 2011. Extension communication channels' usage and preference by farmers in Benue State, Nigeria. Journal of Agricultural Extension and Rural Development Vol. 3(5), pp. 88-94, May 2011. Available online http:// academicjournals.org/JAERD 
Pertiwi, P Rospina. 2009. Persepsi Dan Pemilihan Petani Terhadap Saluran Komunikasi Penyuluhan Mengenai Informasi Pengelolaan Usahatani Padi (Kasus Petani Kabupaten Serang) (Perception and Decision of Farmers on Outreach Communication Channels Regarding Information on Rice Agribusiness Management--The Case of Serang District Farmers). Thesis. Bogor. Institut Pertanian Bogor

Rahayu RB. 2011. Preferensi Resiko Petani Pada Usahatani Padi Organik Di Kabupaten Sragen (Farmers' Risk Preferences on Organic Rice Agribusiness in Sragen District). Postgraduate Thesis. Bogor : IPB

Rogers, E. M. And F.F. Shoemaker. 1971. The Communication of Innovation. $2^{\text {nd }}$ Edition. New York: The Free Press.

Rogers and Shoemaker. 1986. Memasyarakatkan Ide-ide Baru (Socializing New Ideas). Surabaya: Usaha Nasional.

Siegel, S. 1994. Statistik Non Parametrik untuk Ilmu-ilmu Sosial (Non Parametric Statistic for Social Sciences). Jakarta: Gramedia

Suhardjono. 2006. Gerakan Pertanian Organik Sebagai Bentuk Gerakan Moral (Organic Farming Movement as Moral Movement) in: Seputra AW, et al. (Editor). Bunga Rampai XIV: Pangan Dan Pemberdayaan Petani (Anthology XIV: Food and Farmer Empowerment). Jakarta (ID): LDDKAJ and PSE/KWI Commission.

Walpole, Ronald E. 1995. Pengantar Statistika: Edisi Ke-3 (Introduction to Statistics: $3^{\text {rd }}$ Edition). Jakarta: PT Gramedia Pustaka Utama.

Widiarta, et al. 2011. Analisis Keberlanjutan Praktik Pertanian Organik di Kalangan Petani (Analysis of Organic Farming Sustainability Among Farmers) Jurnal Sodality. Vol 05 (04) No. 01: 71-89 